Dragan Pamučar, poručnik, dipl. inž.

Vojna akademija Beograd
PRIMENA SWOT ANALIZE NA SISTEM INTEGRALNOG TRANSPORTA VOJSKE SRBIJE

UDC: $355.415 .2 / .3(497.11)$

Rezime:

U radu je prikazana primena SWOT analize na sistem integralnog transporta Vojske Srbije. Kao rezultat analize predstavljeni su ciljevi daljeg usavršavanja integralnog transporta, kao i mogući problemi generisani strateškim upravljanjem.

Ključne reči: integralni transport, SWOT analiza.

\title{
SWOT ANALYSIS OF THE INTERMODAL TRANSPORTATION SISTEM IN THE ARMY OF SERBIA
}

Summary:

This work presents the SWOT analysis application to the intermodal transportation sistem in the Army of Serbia. The analysis resulted in defining goals for the future development of intermodal transportation, as well as possible problems generated by strategic management.

Key words: intermodal transportation, SWOT analysis.

\section{Uvod}

Savremeni tržišni uslovi brzo uništavaju one koji nisu spremni ni sposobni da inoviraju ili, u najmanju ruku, da se adaptiraju. Otuda su se, u drugoj polovini XX veka, u menadžmentu preduzeća pojavili i vojni termini, kao što su strategija i taktika vođenja operacija preduzeća. U tu svrhu razvijene su savremene metode i tehnike strateškog menadžmenta, kao što su [1]: portfolio koncept, benčmarking, SWOT (TOWS) matrica, kriva iskustva, PIMS, metod scenarija, analiza jaza (gepa), matrica analize šansi i opasnosti i drugo. Sve one nalaze svoju primenu u raznim oblastima i organizacijama, pa i u vojnim. Međutim, u Vojsci Srbije ni jedna od navedenih tehnika do sada nije dovoljno eksploatisa- na. U skladu sa aktivnostima koje su usmerene na reformu sistema odbrane, $\mathrm{u} \mathrm{VS}$, a posebno u oblasti transporta, stvorene su mogućnosti i za primenu metoda iz oblasti strateškog menadžmenta.

Metoda strateškog menadžmenta koja je u dosadašnjoj primeni postigla najveći efekat je SWOT analiza. Naziv SWOT (TOWS) nastao je od početnih slova engleskih reči Threats (pretnje), Opportunities (šanse), Weaknesses (slabosti) i Strenghts (jačina). SWOT analiza je metoda koja u okviru preduzetih reformskih aktivnosti može da posluži kao pogodan alat za procenu onoga što u organizaciji treba eliminisati, delimično zadržati ili zadržati u potpunosti. Ova metoda je jednostavna i izuzetno primamljiva za istraživače. 
Osnovna ideja SWOT analize jeste utvrđivanje internih snaga i slabosti, kao i eksternih pretnji i mogućnosti. Na taj način ostvaruje se kontinuiran napredak i razvoj, a samim tim i konkurentska prednost.

Osnovni cilj ovoga rada jeste da se postave smernice upotrebe SWOT analize u transportu VS, odnosno u njegovom delu integralnog transporta.

\section{Pojam strateškog menadžmenta}

Strateški menadžment (po nekim autorima: upravljanje) jeste proces pomoću kojeg menadžeri formulišu i primenjuju strategije, kojima će se omogućiti dostizanje strateških ciljeva na optimalan način u datim uslovima okruženja i samog preduzeća. U najširem smislu može se definisati kao svesno usmeravanje poslovnog sistema $u$ skladu sa njegovim relevantnim okruženjem. To znači da je osnovni smisao strateškog menadžmenta obezbeđenje uspešnog funkcionisanja svakog preduzeća u promenljivim uslovima poslovanja. Naime, dinamičnost promena u okruženju prouzrokuje potrebu za adekvatnim prilagođavanjem preduzeća koja se bave transportom. Zato se potreba strateškog menadžmenta postavlja kao imperativ, imajući u vidu da se preduzeća koja se bave transportom uspešno prilagođavaju promenama u složenom dinamičkom okruženju, odnosno da se saobraćajni sistem u celini efikasno inkorporira $\mathrm{u}$ evropski i svetski saobraćajni sistem. S druge strane, izbor strategije razvoja predstavlja jedno od najznačajnijih i najsloženijih pitanja $u$ poslovanju svakog preduzeća, za čije projektovanje je potrebno ne samo dobro poznavanje relevantnog okruženja, već i samog preduzeća.
Strateški menadžment može da se definiše kao [1]: proces usmeravanja aktivnosti preduzeća kojim se, na bazi anticipacije šansi i opasnosti, na jednoj strani, i jakih i slabih strana preduzeća, na drugoj, identifikuju kritični faktori poslovnog uspeha, te, shodno prethodno utvrđenoj strateškoj viziji, opredeljuje misija, razvojni ciljevi, kao i pravci, metodi $\mathrm{i}$ instrumenti njihove optimalne realizacije u dinamičkoj poslovnoj sredini.

\section{Razvoj strateškog menadžmenta}

Strateški menadžment nastao je kao rezultat spajanja najboljih ideja dva odvojena, paralelna, često međusobno isprepletana područja razmišljanja. Jedno su ideje i pogledi koji su razvijeni u okviru predmeta poslovne politike koja se izučava u poslovnim školama, a drugo je koncept dugoročnog poslovnog planiranja. Naime, dok poslovna politika uključuje principe i kriterijume za harmonično upravljanje resursima, funkcionalnim područjima i organizacionim delovima, dotle dugoročno planiranje obuhvata utvrđivanje ciljeva i strategija, odnosno odgovor na pitanja kao što su: gde je preduzeće sada, gde treba da bude i kako stići tamo? [1].

Strateški menadžment je stekao punu afirmaciju u poslovnoj praksi i literaturi i šroko je prihvaćen kao nezaobilazan predmet u većini institucija koje se bave obrazovanjem savremenih menadžera.

Razvoj strateškog menadžmenta može se sagledati i kroz razvoj sistema poslovnog planiranja, s tim da se obično navode četiri sledeće faze [1]:

- Prva faza je bazično finansijsko planiranje koje je karakteristično za mala i novoformirana preduzeća. Težište je na 
pripremi i ostvarenju godišnjeg budžeta, pa planiranje služi kao osnova operativne kontrole poslovanja. Otuda se radi o kratkoročnom (tekućem i operativnom) planiranju i fokusu na funkcionalnim područjima gde, obično, nije zastupljeno predviđanje već se koriste analize i standardi iz proteklog perioda.

- Drugu fazu karakteriše ozbiljnije uvažavanje predviđanja kao pretpostavke planiranju. Naime, rast i razvoj preduzeća zahtevaju širi prostorni i duži vremenski horizont za osmišljavanje njegovog poslovanja, te se poseže za analizama okruženja i dugoročnijim prognozama. Međutim, ovde se još uvek radi o pasivnom odnosu prema sredini, u smislu da se u okviru prognoziranog toka događaja u sredini vrši statička alokacija resursa bez pretenzija da se tok događaja preusmeri.

- Treća faza je eksterno orijentisano planiranje, koje je karakteristično za zrelija i, po širini programa, složenija preduzeća koja su spoznala prirodu tržišnog ambijenta, te uvažavaju marketing koncept $\mathrm{u}$ orijentaciji i realizaciji svoga poslovanja. Dinamičnost marketing sredine i umnožavanje alternativa za reagovanje preduzeća afirmišu strateško razmišljanje, pa se za identifikovanje i izbor strategije ponašanja preduzeća zahteva temeljnija analiza i predviđanje domaćeg i međunarodnog tržišta, uključujući i analizu konkurencije. U ovoj fazi karakteristična je dinamička alokacija resursa.

Konačno, poslednju četvrtu fazu obeležava dominacija strateškog menadžmenta i pretenzija da se kroz razvijeni sistem predviđanja $i$, na njemu zasnovan sistem strateškog planiranja, utiče na događaje u sredini.

\section{Opšti model strateškog menadžmenta}

Cilj strateškog menadžmenta jeste traženje odgovora preduzeća na promene do kojih dolazi u okruženju u kojem ono posluje. S druge strane, strateški menadžment treba da ukaže na konkurentske prednosti i nedostatke preduzeća i njegove delatnosti. To znači da treba da identifikuje postojeće i buduće probleme preduzeća i predvidi odgovarajuće načine i akcije za njihovo rešavanje pomoću raspoloživih resursa (kadrovskih, materijalnih, finansijskih i informacionih) u postojećim i očekivanim uslovima poslovanja [1].

U literaturi je, uglavnom, prihvaćen opšti model strateškog menadžmenta koji se sa određenim modifikacijama može primeniti na saobraćajna preduzeća, kao i na saobraćaj kao sistem u celini. Ovaj model sadrži sledeće elemente [1]:

- snimak i analizu okruženja,

- formulisanje strategije,

- sprovođenje strategije,

- kontrolu sprovođenja strategije.

Da bi definisali strateške ciljeve i odgovarajuće strategije za njihovu realizaciju neophodno je izvršiti analizu okruženja u kome preduzeće posluje. Ova analiza obuhvata snimak i analizu najznačajnijih faktora koji izazivaju promene i značajno utiču na poslovanje i razvoj preduzeća i potencijala kojima preduzeće raspolaže.

Eksternu sredinu preduzeća čine svi elementi (pojedinci, organizacije, institucije) i faktori (ekonomski, politički, pravni, tehnološki, sociokulturni, ekološki i sl.) koji imaju stvarni ili potencijalni uticaj na rezultate poslovanja preduzeća. 
Analiza eksterne sredine ima za rezultat identifikovanje mogućnosti i opasnosti. Opstanak preduzeća (po modelu prirodne selekcije) zavisi od usklađenosti strukturnih karakteristika preduzeća i karakteristika sredine. Sredina omogućava opstanak samo onim preduzećima koja se uspešno prilagođavaju promenama.

Potreba da se ostvari profit može biti u konfliktu sa željom društva za odgovornim ponašanjem. Zbog toga država, radeći u interesu društva kao celine, donosi i sprovodi zakone koji regulišu ponašanje preduzeća (štite se potrošači, konkurencija, životna sredina, itd.). Pored ekonomske odgovornosti (biti rentabilan), pravne odgovornosti (uvažavati zakon) i etičke odgovornosti (obaveza da se radi ono što je opravdano i fer, izbegavati štetu) od preduzeća se očekuje i filantropska odgovornost (da preduzeće bude dobar građanin, da svojim sredstvima doprinosi poboljšanju kvaliteta života).

Projektovanje strategije razvoja preduzeća predstavlja izuzetno složen i kompleksan zadatak. Strategija obuhvata projektovanje dugoročnih planova preduzeća za efikasno upravljanje poslovanjem i razvojem. Strategiju čine sledeće faze [2]:

- definisanje misije,

- definisanje ciljeva,

- projektovanje strategije,

- postavljanje smernica za politiku.

Misija predstavlja svrhu poslovanja i filozofiju preduzeća. To znači da se misijom određuje identitet preduzeća definisanjem njegove svrhe i filozofije, pri čemu se razlikuje od drugih, odnosno definiše se sadašnja i buduća delatnost preduzeća. U tom smislu ona treba da bude tako definisana da omogućava opti- malno projektovanje ciljeva koje preduzeće treba da postigne.

Kao kriterijum za formulisanje misije mogu se koristiti:

- osnovna definicija transportne usluge;

- definisanje korisnika transportnih usluga, kao transportnog tržišta;

- filozofija transportnih preduzeća;

- odgovornost prema društvu;

- javni imidž preduzeća i dr.

Pri definisanju misije moraju se uzeti u obzir istorija preduzeća, njegove jake i slabe strane, šanse i ograničenja, kao i raspolaganje materijalnim, finansijskim i informacionim resursima. Misija saobraćajnog preduzeća može da bude: „da korisnicima obezbedi transportne usluge visokog kvaliteta sa konkurentnom cenom na domaćem i međunarodnom tržištu“" [3].

U poslednje vreme, kako u literaturi tako i u poslovnoj praksi, sve više se govori o viziji kao osnovnoj pretpostavci strateškog menadžmenta. Ona predstavlja dalekosežan pogled u budućnost i izraz nameravanih pravaca razvoja preduzeća. Osobine dobre vizije su [3]:

- zamisliva: prenosi sliku o tome kako će izgledati budućnost;

- privlačna: pogodna u odnosu na dugoročne interese zaposlenih čiji su interesi prisutni u preduzeću;

- moguća: sadrži realne, ostvarljive ciljeve;

- fokusirana: dovoljno jasna da usmeri donošenje odluka;

- fleksibilna: dovoljno opšta da dozvoli individualnu inicijativu i alternativne oblike reagovanja $\mathrm{s}$ obzirom na promenljive uslove; 
- pogodna za komunikaciju: lako se prenosi drugima, može uspešno da se objasni u roku od 5 minuta.

Moguće vizije saobraćajnog preduzeća su [4]:

- da bude lider na tržištu transportnih usluga;

- da ostvaruje najveći kvalitet usluga u svojoj oblasti,

- da ostvaruje najbolje finansijske rezultate u svojoj oblasti;

- da bude najatraktivnije preduzeće za kadrove u svojoj oblasti;

- da sarađuje sa najboljim partnerima u realizaciji usluga.

$\mathrm{Na}$ osnovu definisanja misije potrebno je utvrditi dugoročne ciljeve preduzeća, definisanjem njihovog prioriteta. Strategija predstavlja osnovni plan kojim se definiše način na koji će preduzeće realizovati svoju misiju i ciljeve, odnosno na koji način će preduzeće angažovati materijalne, finansijske, kadrovske $\mathrm{i}$ informacione resurse.

Sprovođenje strategije predstavlja proces realizacije izabrane alternativne strategije koji se često naziva operativnom strategijom.

U praksi se strategija sprovodi pomoću ljudi koji se nalaze na različitim nivoima organizacije. Sprovođenje strategije organizacije i strategija poslovnih jedinica vezano je za operativni menadžment, odnosno za operativne strategije koje se odnose na pojedine poslovne funkcije (marketing strategija, proizvodna strategija, strategija kadrova, finansijska strategija). Posebno je značajno da se uspešno integrišu sve pojedine operativne strategije. Od posebnog je značaja privrženost, angažovanje i zainteresovanost svih zaposlenih kao i sistem nagrađivanja. Kontrola sprovođenja strategije ima za cilj otklanjanje određenih nedostataka i usavršavanje primenjenog modela strategije [1].

Menadžeri zato treba da imaju posebne veštine da sagledaju i prevaziđu prepreke i da obezbede efikasno obavljanje zadataka. Oni stalno procenjuju kako se strategija sprovodi i da li se ostvaruju ciljevi organizacije.

Kontrola ciljeva može biti kvantitativna i kvalitativna. Dok kontrola ciljeva predstavlja indirektnu kontrolu strategije, u direktnoj kontroli strategije najviše se zagovaraju kvalitativni pristupi, koji se zasnivaju na vrednosnom prosuđivanju menadžmenta.

\section{Teorijske postavke SWOT metode}

Metoda SWOT treba da omogući sistematsku analizu pretnji i šansi, kao i njihovo usaglašavanje sa jakim i slabim stranama preduzeća, dok SWOT analiza predstavlja „alat“ za planiranje strategije kojim se sučeljavaju interne snage i slabosti organizacije sa eksternim šansama i pretnjama. Preduzeće bi trebalo da aktivira snage, prevaziđe slabosti, iskoristi šanse i odbrani se od pretnji (slika).

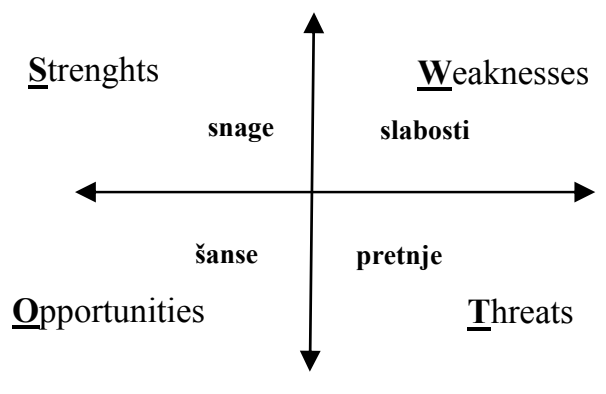

Dijagram SWOT analize 3] 
Na strani eksternih faktora razlikuju se šanse i opasnosti, a u okviru internih mogućnosti utvrđuju se slabe i jake strane preduzeća. Primena SWOT metode u literaturi često se naziva i SWOT analiza, pa će takav pristup biti korišćen i u ovom radu.

Da bi se kompletirala SWOT analiza neophodno je zatražiti od nezavisne grupe individualaca da popune identičnu anketu, kako bi se videlo kako ostali gledaju na celokupno poslovanje preduzeća. Pri tome je veoma važno da se kategorije sortiraju po važnosti.

Poželjno je da SWOT analizu izvrše menadžeri organizacije koji je dobro poznaju, ali u saradnji sa spoljnim konsultantima (koji imaju specijalne analitičke veštine i nezavisno gledanje) zbog objektivnosti. Tipična SWOT analiza izrađuje se kao kvadrat od četiri polja u kojima se definiše svaki od ova četiri faktora. Time što se okruženje analizira kroz detaljan spisak povoljnih (šanse) i nepovoljnih (pretnje) faktora stimulira se istraživački napor i obezbeđuje realnost $\mathrm{u}$ definisanju strategija. Prema tome, sučeljavanjem eksternih (šanse i pretnje) i internih (slabosti i sposobnosti) faktora može se identifikovati nekoliko tipova mogućih strategija ponašanja preduzeća (tabela 1):

- mini-mini strategija (WT), koja uključuje minimiziranje slabosti i pretnje. Primenjivaće je preduzeće kada se nađe u situaciji da mu je okruženje nepovoljno, a preduzeće ima niz internih slabosti. U takvoj situaciji ono je pred dilemom da li da se bori za spas ili da ide u likvidaciju. Moguće je, međutim, ići i na rešenje da se integriše sa drugim preduzećima ili da drastično smanji obim poslovanja, sa idejom da na taj način prebrodi slabosti i nadom da će se u skoroj budućnosti smanjiti pretnje iz eksternog okruženja;

- mini-maksi strategija (WO), koja podrazumeva minimiziranje slabosti i maksimiziranje šansi. Ova strategijska situacija nastaje kada preduzeće sa stanovišta stanja eksternih faktora ima dobre šanse, ali je opterećeno internim slabostima, pa nije u stanju da iskoristi povoljne izazove okruženja. Preduzeće može, putem razvoja kooperativnih odnosa sa drugim preduzećima koja imaju tehnološki know-how i sl., da minimizira slabosti;

- maksi-mini strategija (ST), koja se odnosi na situaciju kada je preduzeće jako, ali je eksterno okruženje takvo da predstavlja pretnju obimu i vrsti dosadašnje delatnosti. Preduzeće traži načine da iskoristi svoje jake strane i minimizira pretnje. Ono mora biti oprezno da svoje jake strane ne usmeri na pogrešno područje. Moraju se ponekad činiti i određeni kompromisi i prilagođavanje okruženju, ne isključujući ni mogućnost preorijentacije delatnosti ili delovanja na okruženje u pravcu zaustavljanja procesa pogoršanja eksternih okruženja;

- maksi-maksi strategija (SO), koja se odnosi na situaciju kada je preduzeće jako, ali je eksterno okruženje takvo da predstavlja pretnju obimu i vrsti dosadašnje delatnosti. Preduzeće traži načine da iskoristi svoje jake strane i minimizira pretnje. Preduzeće mora biti oprezno da svoje jake strane ne usmeri na pogrešno područje. Moraju se ponekad činiti i određeni kompromisi i prilagođavanje okruženju, ne isključujući ni mogućnost preorijentacije delatnosti ili delovanja na okruženje u pravcu zaustavljanja procesa pogoršanja eksternih okruženja [5]. 
Tabela 1

Utvrđivanje strategija SWOT analizom [3]

\begin{tabular}{|c|c|c|}
\hline $\begin{array}{l}\text { UNUTRAŠNJI } \\
\text { FAKTORI }\end{array}$ & $\begin{array}{l}\text { LISTA UNUTRAŠNJIH } \\
\text { SNAGA }\end{array}$ & $\begin{array}{l}\text { LISTA UNUTRAŠNJIIH } \\
\text { SLABOSTI }\end{array}$ \\
\hline $\begin{array}{l}\text { SPOLJAŠNJI } \\
\text { FAKTORI }\end{array}$ & 1. 1 itd $S$ & $\begin{array}{ll}1 . & W \\
2 . \text { itd } & \text { W }\end{array}$ \\
\hline $\begin{array}{l}\text { LISTA SPOLJAŠNJIIH } \\
\text { MOGUCNOSTI }\end{array}$ & Maxi-Maxi & Mini-Maxi \\
\hline $\begin{array}{ll}\text { 2. } \\
\text { 2. itd } & \mathbf{O}\end{array}$ & so & wo \\
\hline $\begin{array}{l}\text { LISTA SPOLJAŠNJJH } \\
\text { PRETNJI }\end{array}$ & Maxi-Mini & Mini-Mini \\
\hline 2. itd $\quad \mathbf{T}$ & ST & WT \\
\hline
\end{tabular}

Najveća opasnost posle vršenja SWOT analize jeste nepreduzimanje koraka koji bi promenili zatečene karakteristike i osobine. Mnogi izvrše analizu svog preduzeća, ali kasnije nisu u mogućnosti, ili nemaju sredstava, da bilo šta promene u svom poslovanju i poziciji na tržištu. Može se zaključiti da se SWOT analiza može definisati kao sveobuhvatan opis karakteristika i može da bude deo analitičkog odlučivanja.

\section{Primena SWOT analize u sistemu integralnog transporta Vojske Srbije}

Vojska Srbije, kao organizacija koja se finansira isključivo iz budžeta i kojoj je primarni cilj sprovođenje njenih misija, svrstava se u neprofitne organizacije. $\mathrm{S}$ obzirom na odsustvo tržišnog načina poslovanja, Vojsci i njenoj transportnoj podršci SWOT analiza i ostale savremene metode i tehnike strateškog menadžmenta gotovo su nepoznate, odnosno do sada nisu dovoljno primenjivane.

Savremeni svetski bezbednosni trendovi nameću potrebu za reformama vojnih organizacija, kao odgovor na globalne političke i ekonomske promene. Shodno tome, i Vojska mora prepoznati područja u kojima su radikalne promene neophodne, ali i područja u kojima nisu potrebne ili su potrebne u neznatnoj meri. Spoznaja tih područja zahteva duži period konstantnog praćenja aktivnosti usmerenih ka unapređenju ljudskog potencijala i materijalno-tehničkih sredstava, radi stvaranja takve organizacije koja će u potpunosti i sa uspehom moći da odgovori na buduće izazove.

U skladu sa reformama koje se sprovode u okviru sistema odbrane stvorile su se mogućnosti za širu primenu savremenijih metoda iz raznih oblasti strateškog menadžmenta.

SWOT analiza samo je jedna od metoda koja u okviru preduzetih reformskih aktivnosti može da posluži kao pogodan instrument za procenu onoga što treba eliminisati, delimično zadržati ili zadržati u potpunosti. Brzi razvoj nauke, tehnike i tehnologije neminovno utiče na razvoj svih vidova transporta, promenu i usavršavanje strukture saobraćajnog sistema. Razna transportna sredstva i uređaji, zahvaljujući razvoju tehnike, danas mogu da služe različitim potrebama, ali se međusobno dopunjuju i delimično zamenjuju. Time se stvara njegova integralnost, odnosno jedinstveni proces transporta tereta, uvođenjem novih transportnih tehnika i tehnologija. Razna tehnološka rešenja integralnog transporta predstavljaju pravu revoluciju u ovoj oblasti.

Pod pojmom integralni transport podrazumeva se prevoz kompletnih tovarnih jedinica transportnim sredstvima različitih vidova transporta (transportnim sredstvima najmanje dva vida transporta) od pošiljaoca do primaoca tereta. Moderna tehnika i borbena sredstva velikih moguć- 
nosti, koja su masovno zastupljena $\mathrm{u}$ opremi i naoružanju savremenih armija, unela su značajne promene $u$ uslove ratovanja i metode vođenja borbenih dejstava.

Radi definisanja pravaca daljeg razvoja sistema integralnog transporta sprovedena je SWOT analiza uticaja, tj. šansi i pretnji okruženja na sistem integralnog transporta u Vojsci.

Pri određivanju slabih strana integralnog transporta neophodno je da se odgovori na sledeća pitanja:

Šta je potrebno poboljšati u sistemu integralnog transporta VS?

Šta je potrebno promeniti?

Šta treba da se uradi da bi se poboljšale performanse integralnog transporta?

Da bi se u potpunosti iskoristile šanse veoma je bitno da se poznaju trendovi u sektoru integralnog transporta.

Opasnosti okruženja za integralni transport predstavljaju ključ protiv kojeg treba da se usmere napori održanja i daljeg razvoja integralnog transporta. Opasnosti okruženja mogu se ogledati u odlivu kvalitetnog kadra, nepostojanju strategije razvoja - nacionalne i regionalne, zakonske regulative, inflacije, nedostatku finansijskih sredstava ili visokoj ceni, itd.

Jake strane integralnog transporta $u$ Vojsci mogu se naglasiti ako se odgovori na neka od sledećih pitanja:

Kako iskoristiti jake strane integralnog transporta za korišćenje šansi okruženja?

Kako iskoristiti jake strane integralnog transporta za odbranu od opasnosti okruženja?

Kako slabosti integralnog transporta mogu uticati na korišćenje šansi okruženja?
Kako slabosti integralnog transporta mogu da utiču na odbranu od opasnosti okruženja?

Šanse u okruženju mogu se kvalitetno sagledati odgovorom na neka od sledećih pitanja:

Gde su dobre prilike?

$\mathrm{Na}$ koje interesantne trendove treba obratiti pažnju?

Za pravilnu izradu SWOT analize veoma je bitno da menadžer bude realan. U nekim slučajevima je dobro da se stavi u poziciju kupca, ili trećeg lica, i odgovori na pitanje „Koje jače strane vašeg preduzeća vide vaši korisnici?“

Nakon analiziranja internih i eksternih faktora pristupa se formulaciji strategija razvoja integralnog transporta VS. Formulisane su dve strategije razvoja integralnog transporta:

- „maksi-maksi“, koja predstavlja najpovoljniji tip strategijske situacije. U takvim uslovima sistem integralnog transporta maksimalno koristi svoje prednosti i raspoložive šanse radi daljeg razvoja;

- „mini-mini“, koja uključuje minimiziranje slabosti i pretnji. Ova strategija je izabrana zbog nepovoljnih uslova okruženja za razvoj integralnog transporta (slaba ekonomska moć države, zastarela sredstva...), a i sam sistem integralnog transporta u VS obiluje nizom internih slabosti. U takvoj situaciji sistem integralnog transporta u VS može drastično da smanji obim svojih aktivnosti, sa idejom da na taj način prebrodi slabosti i nadom da će se u skoroj budućnosti smanjiti pretnje iz eksternog okruženja. 
Faktori ,,maksi-maksi“" strategije

\begin{tabular}{|c|c|}
\hline Snaga (Strengths) & Šanse (Opportunities) \\
\hline $\begin{array}{l}\text { - mogućnost brze predi- } \\
\text { slokacije jedinica, } \\
\text { - racionalizacija celo- } \\
\text { kupnog sistema distri- } \\
\text { bucije robe, } \\
\text { - povećanje bezbednosti } \\
\text { rada radnika pri mani- } \\
\text { pulaciji teretima, } \\
\text { - zaštita tovarnih jedini- } \\
\text { ca od atmosferskih uti- } \\
\text { caja, } \\
\text { - informativnost u pogle- } \\
\text { du količine i vrste robe } \\
\text { u skladišnim objekti- } \\
\text { ma, } \\
\text { - uspešan i brz manevar } \\
\text { logističkih jedinica, } \\
\text { - povećanje proizvodno- } \\
\text { sti rada transportnih } \\
\text { sredstava, } \\
\text { - povećanje broja obrta } \\
\text { transportnih sredstava, } \\
\text { - brzo manipulisanje i } \\
\text { transport materijalno- } \\
\text { tehničkih sredstava, } \\
\text { - smanjenje vremena za- } \\
\text { državanja transportnih } \\
\text { sredstava na utovarnim, } \\
\text { istovarnim i pretovar- } \\
\text { nim radnim mestima. }\end{array}$ & $\begin{array}{l}\text { - formiranje i rad centra } \\
\text { za upravljanje transpor- } \\
\text { tom i integralnim tran- } \\
\text { sportom u Vojsci, } \\
\text { - povećanje saradnje } \\
\text { Vojske sa ministarstvi- } \\
\text { ma nadležnim za po- } \\
\text { slove u oblasti integral- } \\
\text { nog transporta, } \\
\text { - modernizacija postoje- } \\
\text { ćih i uvođenje racional- } \\
\text { nih integralnih sistema } \\
\text { (sistem paleta i kontej- } \\
\text { nera), } \\
\text { - kompatibilnost tran- } \\
\text { sportnog sistema Voj- } \\
\text { ske Srbije sa transport- } \\
\text { nim sistemom u druš- } \\
\text { tvu, } \\
\text { - standardizacija infor- } \\
\text { macionih tehnologija u } \\
\text { oblasti transporta, } \\
\text { - izgradnja i adaptacija } \\
\text { skladišta za primenu } \\
\text { integralnog transporta, } \\
\text { - povezanost skladišnih } \\
\text { kompleksa sa ostalim } \\
\text { vidovima transporta, } \\
\text { - uvođenje i rukovođenje } \\
\text { podsistema paletizacije } \\
\text { u svim službama VS, } \\
\text { - poboljšanje saradnje sa } \\
\text { stranim armijama (NA- } \\
\text { TO) po pitanju iskusta- } \\
\text { va u integralnom tran- } \\
\text { sportu, } \\
\text { - unapređenje sistema } \\
\text { obuke rukovaoca sred- } \\
\text { stvima integralnog } \\
\text { transporta, } \\
\text { - operativna evidencija i } \\
\text { uvooenje automatizo- } \\
\text { vanog pracenja sredsta- } \\
\text { va integralnog tran- } \\
\text { sporta (IT), } \\
\text { - izrada tehničke doku- } \\
\text { mentacije za svako } \\
\text { sredstvo IT-a (opis, ru- } \\
\text { kovanje, održavanje...), } \\
\text { - definisanje normativa } \\
\text { za opremanje IT-a } \\
\text { svim elementima kon- } \\
\text { tejnerskog sistema, na } \\
\text { osnovu tokova materi- } \\
\text { jalnih sredstava, } \\
\text { - obrazovanje stručnih } \\
\text { kadrova i izučavanje } \\
\text { savremenih transport- } \\
\text { nih tehnologija. }\end{array}$ \\
\hline
\end{tabular}

Faktori ,mini-mini “ strategije

\begin{tabular}{|c|c|}
\hline Slabosti (Weaknesses) & Pretnje (Threats) \\
\hline $\begin{array}{l}\text { - nepostojanje strategije } \\
\text { razvoja integralnog } \\
\text { transporta na nivou } \\
\text { Vojske, } \\
\text { - nije definisano finansi- } \\
\text { ranje sistema integral- } \\
\text { nog transporta, tj. fi- } \\
\text { nansiranje pojedinih } \\
\text { segmenata planira se na } \\
\text { različitim mestima, } \\
\text { - nepravovremeno rešava- } \\
\text { nje organizacijsko-forma- } \\
\text { cijskog pitanja (obuka ru- } \\
\text { kovalaca sredstvima, lič- } \\
\text { na i materijalna formaci- } \\
\text { ja), } \\
\text { - nepostojanje akumulator- } \\
\text { skih stanica u skladišti- } \\
\text { ma, neophodnih za popu- } \\
\text { nu akumulatora sredstava } \\
\text { za manipulaciju na elek- } \\
\text { trični pogon, } \\
\text { - 15\% skladišnih objeka- } \\
\text { ta je prilagođeno za rad } \\
\text { sredstava IT-a } \\
\text { - 85\% skladišta u Vojsci } \\
\text { ne zadovoljava uslove } \\
\text { neophodne za rad sred- } \\
\text { stava za manipulaciju } \\
\text { (maks. uspon i pad 3- } \\
\text { 7\%), } \\
\text { - neprilagođenost tran- } \\
\text { sportnih sredstava zah- } \\
\text { tevima IT-a produžava } \\
\text { radnu operaciju, } \\
\text { - nepovoljan stepen isko- } \\
\text { rišcenja tovarne i zapre- } \\
\text { minske nosivosti tran- } \\
\text { sportnih sredstava, } \\
\text { - nepostojanje razmene } \\
\text { iskustava - dobre prak- } \\
\text { se sa stranim armijama, } \\
\text { - neprilagođenost prila-- } \\
\text { znih saobraćajnica ter- } \\
\text { minalima za sredstva } \\
\text { IT-a, } \\
\text { - neusklađenost tehničko- } \\
\text { konstruktivnih karakteri- } \\
\text { stika transportnih sred- } \\
\text { stava različitih vidova } \\
\text { saobraćaja za potrebe } \\
\text { IT-a, } \\
\text { - nepostojanje standardiza- } \\
\text { cije u oblasti integralnog } \\
\text { transporta Vojske, } \\
\text { - zastarelost skladišnih } \\
\text { objekata i infrastruktu- } \\
\text { re (izgrađeni pre } 30 \text { go- } \\
\text { dina), } \\
\text { - neusklađenost skladišnih } \\
\text { objekata i infrastrukture } \\
\text { zahtevima savremenih } \\
\text { tehnologija transporta. }\end{array}$ & $\begin{array}{l}\text { - parcijalna rešenja, bez } \\
\text { prethodnih istraživanja } \\
\text { i usvajanja mogu da } \\
\text { budu krupan tehnički i } \\
\text { materijalni promašaj, } \\
\text { - nedostatak investicio- } \\
\text { nih ulaganja u dalji raz- } \\
\text { voj sistema IT-a, } \\
\text { - veći zahtevi za zaštitu } \\
\text { životne sredine, } \\
\text { - smanjenje nivoa koor- } \\
\text { dinacije po pitanju in- } \\
\text { tegralnog transporta iz- } \\
\text { među državnih organa, } \\
\text { stručnih organizacija i } \\
\text { institucija i Vojske, } \\
\text { - smanjenje motivacije } \\
\text { angažovanih stručnih } \\
\text { lica usled višegodiš- } \\
\text { njeg napora a malih po- } \\
\text { maka, } \\
\text { - odlazak stručnog kadra } \\
\text { iz oblasti integralnog } \\
\text { transporta iz vojne } \\
\text { organizacije. }\end{array}$ \\
\hline
\end{tabular}


Na osnovu sprovedene SWOT analize izvedeni su sledeći ciljevi, koje je neophodno sprovesti radi poboljšanja sistema integralnog transporta u Vojsci Srbije:

- standardizacija tovarnih jedinica i transportnih i pretovarnih sredstava $i$ informatike u oblasti transporta;

- obezbeđenje kvalifikovanih rukovalaca sredstvima integralnog transporta u jedinicama i ustanovama. Stoga je potrebno da se u saradnji sa taktičkim i tehničkim nosiocima obezbede uslovi i mogućnost izvođenja obuke, ne samo rukovalaca skladišnom mehanizacijom već $i$ upravnih organa;

- sredstva manipulacije i pakovanja u VS ne smeju se usvojiti bez saglasnosti saobraćajne službe zbog potrebe usaglašavanja. Izrazit problem predstavljaju sredstva pakovanja (osnovna i transportna) koja treba da odgovore zahtevima tehnologija integralnog transporta, a većina taktičkih nosilaca ih ne poznaje i stalno stvara terete, koji ne odgovaraju paletizaciji i kontejnerizaciji;

- propisivanje svih vrsta tipova i sredstava skladišne mehanizacije, određivanje perspektivnosti, definisanje sredstava i opreme koji treba da se vode po operativnoj evidenciji i uvođenje u automatizovano praćenje;

- regulisanje postupka sa sredstvima skladišne mehanizacije koja nisu na listi perspektivnih i odrediti kada im završava životni ciklus;

- izrada tehničke dokumentacije za svako sredstvo posebno (samo za perspektivna sredstva);

- sve tehničke radionice i tehničke remontne zavode osposobiti za izvršavanje radova lakog, srednjeg i generalnog remonta na sredstvima integralnog transporta putem: obuke stručne radne snage kod proizvođača i servisera sredstava integralnog transporta, opremanja radionica alatima, opremom i uređajima za dijagnosticiranje, servisno održavanje i remont, kao i opremanja tehničkih radionica rezervnim delovima;

- izgradnju novih i adaptaciju postojećih skladišta obavljati po savremenoj metodologiji i taktičko-tehničkim zahtevima;

- pri uvođenju kontejnerskog sistema transporta neophodna su prethodna sistemska i druga programirana istraživanja i opitovanje, jer parcijalna rešenja mogu doneti velike tehničke i materijalne promašaje;

- neophodno je da se odredi mesto kontejnerskog podsistema u sistemu integralnog transporta, pouzdanost i razgraničenost sa podsistemom paleta i ostalim sistemima transporta, i da se, na osnovu toga i tokova materijalnih sredstava, definišu normativi za opremanje elementima kontejnerskog sistema;

- potrebno je da se predloži optimalno organizacijsko rešenje funkcionisanja kontejnerskog sistema u logističkoj podršci VS i zemlje u celini u jedinstvenom transportnom sistemu, sa alternativama vezanim za materijalna ulaganja i efekte.

\section{Zaključak}

Savremene organizacije su, prateći trendove razvoja, odavno inkorporirale metode i tehnike strateškog menadžmenta u svoje funkcionisanje. Metode i tehnike strateškog menadžmenta u VS gotovo su nepoznate, odnosno do sada nisu ili su retko primenjivane u njenoj organizaciji. 
Aktuelni proces reforme sistema odbrane mora doneti promene i na tom planu. SWOT analiza i ostale metode strateškog menadžmenta $\mathrm{u}$ okviru tog procesa moraju da zauzmu mesto koje im pripada. Pri tome treba istaći da u primeni SWOT analize uopšte, pa samim tim i u saobraćajnoj podršci VS, treba biti obazriv, jer ova analiza je dijagnostičko sredstvo koje treba shvatiti kao pomoć (alat) menadžmentu. To nije uputstvo već okvir za postavljanje određenih pitanja strateškog karaktera pri sprovođenju situacione analize ili formulisanja strategije.

Saobraćajna služba VS ima potreban kadrovski potencijal, koji će vremenom, zahvaljujući iskustvu, znati kako da maksimalno iskoristi sve prednosti SWOT analize.

Putem interne SWOT analize sticalo bi se iskustvo i menjala svest zaposlenih. Neke od takvih analiza upravo su SWOT analiza $\mathrm{u}$ oblasti integralnog transporta VS. Takve i slične studije veoma su značajne za oporavak i transformaciju kompletnog odbrambenog sistema države.

Shodno tome, osnovni pravci delovanja u funkciji unapređenja poslovne prakse Vojske Srbije bili bi:

- široka i sveobuhvatna primena metoda strateškog menadžmenta u Vojsci, posebno u njenoj logističkoj podršci,
- stalno unapređenje znanja svih zaposlenih, posebno menadžera na nižim hijerarhijskim nivoima,

- promena načina ponašanja, primenom savremenih menadžment tehnika,

- prihvatanje tržišne logike poslovanja, u meri u kojoj je to moguće i opravdano...

Ne treba zanemariti činjenicu da implementacija bilo kakvih promena zavisi od spremnosti organizacije i zaposlenih za promene i prilagođavanje novom načinu rada, kao i to da samo zadovoljni radnici mogu ispuniti očekivanja korisnika i time doprineti unapređenju saobraćajne usluge. Upravo zbog toga SWOT analizu i treba shvatiti samo kao pomoć (alat) menadžmentu. Najvažnija stvar koju menadžment može učiniti jeste da kod radnika probudi svest da su u stanju da urade stvari koje nisu ni znali da mogu da urade, odnosno da ih pokrenu na rad punim kapacitetom.

\section{Literatura:}

1] Milisavljević, M.: Osnovi strategijskog menadžmenta, drugo izdanje, Poslovna škola Megatrend, Beograd, 1999.

2] Milićević, V.: Strategijsko poslovno planiranje - menadžment pristup, FON, Beograd, 1998.

3] Vešović, V.: Menadžment u saobraćaju, peto dopunjeno izdanje, Saobraćajni fakultet, Beograd, 2003.

4] www.cimisys.com.

5] Jovanović, P.: Menadžment - teorija i praksa, drugo izdanje, Grafoslog, Beograd, 1996. 